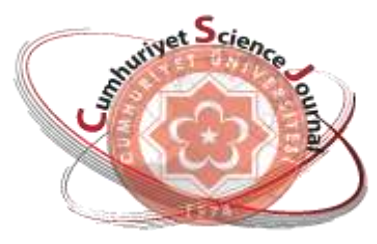

e-ISSN: $2587-246 X$

ISSN: $2587-2680$

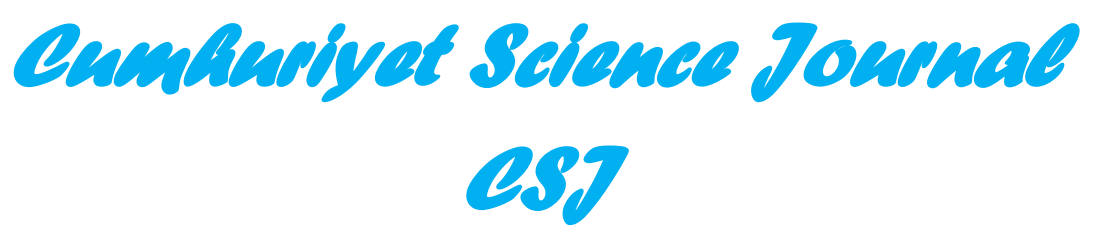

Cumhuriyet Sci. J., Vol.39-1(2018) 80-86

\title{
Technical Aspects of the Quality Management System (QMS) for the Radiation Dosimetry Laboratory at ELI-NP Facility
}

\author{
Dorina ARANGHEL ${ }^{1,2 *}$, Doina STANCIU ${ }^{1,3}$, Chivuta-Ramona BADITA ${ }^{1,4}$, \\ Ana STOCHIOIU ${ }^{1}$, Ion TUDOR ${ }^{1}$

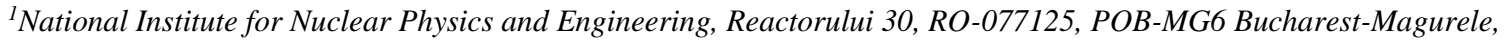 \\ ROMANIA \\ ${ }^{2}$ Extreme Light Infrastructure Nuclear Physics (ELI-NP), Reactorului 30, RO-077125, POB-MG6, Bucharest-Magurele, \\ ROMANIA \\ ${ }^{3}$ University Politehnica of Bucharest, Faculty of Applied Chemistry and Materials Science, Gheorghe Polizu,1-7, Bucharest, \\ ROMANIA
}

${ }^{4}$ University of Bucharest, Faculty of Physics, Atomistilor 405, CP MG - 11, RO-077125, Bucharest-Magurele, ROMANIA

http://dx.doi.org/10.17776/csj.363633

\begin{abstract}
The individual and environmental passive monitoring program of the Extreme Light Infrastructure - Nuclear Physics (ELI-NP) will use a combination of Optically Stimulated Luminescence (OSL) and Solid State Nuclear Track Detector - (SSNTD) detectors. The OSL dosimeters are dedicated for X-rays/gamma radiation monitoring and will contain $\mathrm{BeO}$ detectors which provide the personal dose equivalent and the ambient dose equivalent or the directional dose equivalent according to SR EN 62387-1:2012. The SSNTDs are from poly-allyl diglycol carbonate (CR39), whose performance and test requirements are conform to the criteria of ISO 21909-1:2015 and ISO 8529-3:1998 standards. All the activities of the Radiation Dosimetry Laboratory from ELI-NP will comply the requirements of the ISO/IEC 17025:2005 standard. This paper presents the management of the technical aspects of Quality Management System (QMS) implemented in the Radiation Dosimetry Laboratory ELI-NP facility, Romania. The accuracy and reliability of laboratory tests are determined by factors such as human factors; accommodation and environmental conditions; methods of analyzing and validating methods; used equipment; traceability of the measurement; sampling; manipulation of measurement items. All of the factors above will contribute to total measurement uncertainty. For this purpose an important role it has the effective management of the technical aspects of the QMS.
\end{abstract}

Keywords: Radiation dosimetry, Quality Management System (QMS)

\section{ELI-NP Tesislerinde Radyasyon Dozimetri Laboratuvarı için Kalite Yönetim Sisteminin (QMS) Teknik Yönleri}

Özet: ELI-NP (Aşırı Hafif Altyapı - Nükleer Fizik) 'nin bireysel ve çevresel pasif izleme programı, Optik Uyarılmış Lüminesans (OSL) ve Katı Hal Nükleer İz Dedektörü (SSNTD) dedektörlerinin bir kombinasyonunu kullanacaktır. OSL dozimetreleri, X-1şınları/gama radyasyon izlemesi için ayrılmışlardır ve kişisel doz eşdeğerini ve ortam dozu eşdeğerini veya SR EN 62387-1: 2012'ye göre yönelimli doz eşdeğerini sağlayan BeO detektörlerini içerecektir. SSNTD'ler,

* Corresponding author. Email address: daranghe@nipne.ro

http://dergipark.gov.tr/csj $\quad$ (C2016 Faculty of Science, Cumhuriyet University 
performans ve test gereklilikleri ISO 21909-1: 2015 ve ISO 8529-3: 1998 standartlarına uygun olan poli-allil diglikol karbonattan (CR39) oluşmaktadır. ELI-NP'den Radyasyon Dozimetri Laboratuvarı'nın tüm aktiviteleri ISO/IEC 17025: 2005 standardının gerekliliklerini karşılayacaktır. Bu makale, Romanya'daki Radyasyon Dozimetri Laboratuvarı ELI-NP tesisinde uygulanan Kalite Yönetim Sisteminin (QMS) teknik yönlerinin yönetimini sunmaktadır. Laboratuvar testlerinin doğruluğu ve güvenilirliği, insan faktörleri; konaklama ve çevre koşulları; yöntemleri analiz etme ve doğrulama yöntemleri; kullanılan ekipman; ölçümün izlenebilirliği; örnekleme; ölçüm öğelerinin manipülasyonu ile belirlenir. Yukarıdaki faktörlerin tümü, toplam ölçüm belirsizliğine katkıda bulunacaktır. Bu amaçla, QMS'nin teknik yönlerinin etkili bir şekilde yönetilmesi önemli bir rol oynar.

Anahtar Kelimeler: Radyasyon dozimetrisi, Kalite Yönetim Sistemi (QMS)

\section{INTRODUCTION}

The personnel monitoring of external exposures intend to provide information on the external radiation exposure of individuals working with radioactive materials and/or radiation producing devices to allow control of the workplace (ICRP60, 1991; ICRP-75, 1997). By means of such monitoring it is hoped to limit the exposure of such personnel to within prescribed limits, which are based on recommendation of international and national bodies. These results assist those responsible for radiation safety in keeping exposures as low as reasonably achievable ALARA $[1,9]$.

The monitoring program of the Extreme Light Infrastructure - Nuclear Physics (ELI-NP) will use the passive solid state detectors for radiological monitoring of the personnel and environmental radioactivity for the estimation of the dose absorbed. Optically stimulated luminescent (OSL) dosimeters are used for calculating doses due to exposure to photon and beta radiation. So we can evaluate $H H p p(10)$, $H H p p(0,07), H H^{\prime}(0,07)$ and $H H *(10)$ according to SR EN 62387-1. This standard applies to dosimetry systems that measure external photon and/or beta radiation in the dose range between $0,01 \mathrm{mSv}$ and $10 \mathrm{~Sv}$.

The main advantages of the OSL dosimeter are the capabilities of absorbed dose measuring in real time [1], an optimum sensitivity at both the low dose and the high- dose ends of the dose response, the ability to re-read the OSL signal [2, 3]. The OSL dosimeter contain $\mathrm{BeO}$ detectors which can be qualified as tissue equivalent in dosimetric practice [11]. The neutron dosimetry is based on the use of a Solid State Neutron Track Detector (SSNTD) made from PADC (poly-allyl diglycol carbonate), CR-39 based fast and thermal neutron personnel area passive dosimeters. Main advantages of passive neutron devices is that do not requires a power supply during neutron monitoring, on the other hand the disadvantage is that it does not delivers the neutron dose information in real time. [4]. The requirements of this dosimeter are in conformity with ISO 21909-1:2015 and ISO 8529-3:1998 standards. The measurement and/or estimation of neutron dose in radiation environments are critical for radiation protection of occupational workers during normal operating as well as accidental situations [5]. Due to the near tissue equivalence of the material $\mathrm{BeO}[6]$ and since the composition of CR-39 is similar to that of human tissue [5] this dosimeters can be useful for personnel dosimetry. All research and development activities of the Radiation Dosimetry Laboratory from ELI-NP will meet the requirements of the International Standard ISO / IEC 17025: 2005 and will comply with applicable rules and regulations of the National Commission for Nuclear Activities Control (CNCAN). The measured quantities must be precise and the reported values be reliable and 
credible. This goal is achieved by maintaining a Quality Management System according to this international standard [7].

The main activities of the ELI-NP Radiation Dosimetry Laboratory cover the three main areas of monitoring program: radiological monitoring of the personnel, radioactivity of the environment and research in the field of radioprotection. The laboratory will use a Quality Management System (QMS) to demonstrate its capability in testing and calibration activities. Managing the technical aspects of the QMS, according to the technical requirements of ISO/IEC 17025:2005, plays an important role and demonstrates the technical competence, impartiality and integrity of the laboratory in its work. For this purpose, the paper presents guidelines for documentation of QMS procedures by which ELI-NP Radiation Dosimetry Laboratory will ensure the efficient management of technical aspects according to the requirements of this International Standard.

\section{MANAGING THE QMS TECHNICAL ASPECTS}

The correctness and reliability of the tests performed by the laboratory are determined by many factors which include contributions of personnel, accomodation and environmental conditions, equipments, methods of analyzing and validating methods; traceability of the measurement, sampling, handling of measurement items [8]. All of the factors listed above will contribute to total measurement uncertainty and will be taken into account in training and qualification of staff, calibration of equipment used and development of new methods (where appropriate) and analysis procedures.

\section{Personnel}

The personnel is an essential resource by which the ELI-NP Radiation Dosimetry Laboratory demonstrates its technical competence. According to the national regulations, the head of laboratory must be a radiation protection expert and must have a sufficient number of properly qualified and trained staff for job roles for which they are made responsible to carry out specific tasks $[9,10]$. The training will include new staff induction, ongoing quality awareness training. Personnel will have written job descriptions which will clearly define their roles and responsibilities. Selection of staff will be done in accordance with CNCAN regulations that set clear targets for the studies, training and skills of staff working in the field of radioprotection. For new employee staff and for staff performing specific activities, training will be planned and conducted to ensure compliance with QMS requirements [8, 9]. Also, in the laboratory will have appointed the responsible for quality assurance to perform internal audits and staff training in quality assurance [9]. According to the requirements of ISO / IEC 17025: 2005 standard, a procedure will be documented to establish rules for the selection, training and monitoring of laboratory personnel. The training activities will be evaluated in terms of effectiveness, and based on the results obtained, the risks and opportunities resulting from them will be analyzed.

\section{Accomodation and environmental conditions}

In order to ensure the dosimetric testing service, ELI-NP's radiation dosimetry laboratory will have its own space to allow for the correct performance of the activities. Thus the ELI-NP Radiation Dosimetry Laboratory will have [9]:

-Space for testing and calibration dosimetry systems.

-Personnel space, data processing and archiving of dosimetric records. 
Activities will take place in dust-free, controlled temperature and humidity areas, and radiation background monitoring as required by the reference standards describing the test method. According to national regulations, background radiation in the laboratory will not exceed the natural background level. [9]. The environmental and working conditions will be monitored, controlled and recorded for the validation of the test results [8]. In the laboratory shall be effective separation between neighboring areas that carry out incompatible activities, control in laboratry areas as well as recording the environmental abd working conditions, the routine measurement results of the fund [9]. Will be documented the procedures and instructions on the rules of Access to the laboratory and the testing areas, on the cleaning program and on occupational safety rules.

\section{Equipment}

The laboratory will be furnished with all items measurement and test equipment required for the correct performance of the tests [8]. Thus the ELI-NP Radiation Dosimetry Laboratory will be equipped with the systems dosimetric for the doses evaluating for gamma/beta and neutron radiations, sources of radiation necessary to assess the performance of the dosimetric system, equipment for ensuring and monitoring the necessary environmental conditions, according to the standards as well as equipment for conducting research. In the laboratory will perform calibration and / or checking before commissioning and periodically at well-defined intervals and will be established the personnel responsible for the use of equipament, the unique identification mode to indicate calibration status, calibration date, maintenance date, etc [10].

Equipment and its software used for testing are capable of achieving the accuracy required and comply with specifications relevant to the tests and/or calibrations concerned [8]. The ELI-NP Radiation Dosimetry Laboratory will develop a calibration program for all equipment that influences the quality of the test results and radiation sources. Calibration of equipment will be performed at regular intervals, being a requirement of QMS. Assessing sensitivity of dosimeters at well-defined ranges will be done by verifying linearity, reproducibility, relative response caused by average photon radiation energy and incidence angle for each. Also, procedures and work instructions will be established for measures to prevent equipment contamination with radionuclide [10].

Part of the calibration activities that can not be performed by the ELI-NP Radiation Dosimetry Laboratory will be done by an accredited laboratory [9]. For this the selection and supply process will be applied.

The electronic devices for data evaluation, software and hardware will be protected against adjustments that could invalidate the result of attempts [8]. The operating mode and the characteristics of the equipment will be described in the QMS instructions, in accordance with the manufacturer's manual of the equipment and the staff will be trained on their basis, as planned.

\section{Methods of testing and validating the method}

Appropriate methods for the interpretation and recording of measured doses in accordance with requirements established by national authorities and in accordance with appropriate standards shall be used in the laboratory [10]. The annual performance tests to demonstrate the maintenance of the overall performance of the dosimetric system, the monthly routine tests to guarantee proper accuracy and precision of the dosimetric system to measure the dose for a single energy source calibration and periodically quality assurance tests according to QMS show 
that calibration and traceability is met and maintained [9].

Performance acceptance tests and routine tests will be performed in accordance with the methods from the following reference standards: SR EN 62387-1:2012 (Radiation protection equipment. Passive integrated dosimetric systems for environment and staff monitoring) necessary for estimation of the personal dose equivalent and the ambient dose equivalent or the directional dose equivalent to accurate monitoring of X-rays/gamma rays; ISO 219091:2015 (Passive neutron dosimetry systems Part 1: Performance and test requirements for personal dosimetry) and ISO 8529-3:1998 (Reference neutron radiations. Part 3: Calibration of area and personal dosimeters and determination of their response as a function of neutron energy and angle of incidence) standards for neutron dosimetry systems

In addition to the afore-mentioned tests, the laboratory will also carry out the following activities: evaluating radiation doses using the operational quantities [9] $H H_{p p}(10), H H *(10)$ and $H H p p(10)$, reading and erasing of detectors for the purpose of reusability of dosimeters, reporting results, dose registration, archiving of the reports and periodic calibration of laboratory dosimetry systems. The activities listed above will be carried out according to the methods described in QMS working procedures, meeting the references conditions from the test standards and performed by the own laboratory staff with qualification, training and proven experience $[8$, 12]. The working procedures will describe the standard test method and provide information on the dosimetry system used, the data processing and the calculation method for measurement uncertainty. The deviation of the measured value from the reference value shall not be greater than $\pm 10 \%$ in the case of a source for which the uncertainty of measurement is less than 5\% [9]. The data processing will be done according to the calculation formulas presented in the reference standard of the method and described in the QMS procedure. Because dosimetry systems use electronic devices to evaluate and store data, calculations and data transfer will be systematically checked [8]. For this purpose, rules on data protection will be established, respecting the requirements of integrity and confidentiality.

The test methods used will be validated to determine performance using either interlaboratory comparisons or systematic evaluation of factors that influence the result or a combination of both. The records keep during dosimetric testing will indicate whether the established quality parameters have been reached and play an important role for identifying factors that affect uncertainty of measurement and the repeated the test under the same conditions as the initial ones. Through recordings, a rigorous identification of the activities carried out will be carried out [8].

\section{Traceability of measurement}

Measurement traceability is performed by calibrating the dosimetry system and the auxiliary measurement equipment (eg temperature, humidity, natural background, etc.), which have a significant effect on the accuracy of the measurement result [8].

Calibration of the dosimetric system shall be done in accordance with the calibration program developed by the laboratory. The laboratory will check the operation of the dosimetric system, with its own standards, to demonstrate that the operation is performed within the limits of calibration uncertainty.

In order to ensure the traceability of its own standards, the laboratory will have calibration certificates for each of them. The correction factor for these simplified conditions must be 
determined individually for each type of dosimeter [10].

\section{Assuring the quality of test results}

The laboratory will establish quality control procedures to monitor the parameters in order to validate the results. The quality control for conformity assessment will be will be carried out on three levels:

-Primary level realised by the responsible of the test

-Secondary level realised by the responsible of the quality assurance;

-Tertiary level provided by the head of the laboratory.

Parameter monitoring will ensure the performance of the method and that the dosimetric parameters remains within accepted and predefined limits. Data records will be stored and on their basis the quality control charts will be made. When the limits are exceeded, appropiate measures will be taken [8, 10]. Monitoring can be done by participation to interlaboratory comparisons exercises and tests replicated by the same or different methods.

\section{Reporting the results}

The dose reports will meet the requirements of ISO / IEC 17025: 2005 and will contain the information specified by national regulations. In these reports will accurately, unambiguously and objectively mention the measured dose and the monitoring period for each dosimeter identified by number, interpretation of the outcome of compliance with applicable limits and measurement uncertainty and dose accumulated to date [10].

In the test method, details will be provided on how to report the reported data in accordance with CNCAN regulations. The assessed doses will constitute essential QMS records for the purpose of demonstrating compliance with national requirements and the effectiveness of the ALARA principle [9]. The records of the doses will be archiving respect the requirements of national regulations and QMS.

\section{CONCLUSIONS}

Technical aspects of the QMS contributes to the determination of rigor degree required in estimating measurement uncertainty and provides the framework for the implementation of procedures and methods as a result of research activities. The way to managing of the QMS technical aspects will be evaluated periodically by the management of the laboratory and the risks and opportunities arising from them will be analyzed. Based on these analyzes the laboratory will establish measures to reduce risks and the QMS improvement.

The importance of the QMS implementation cannot be ignored. This serve as a passport to success for the performance of dosimetry systems (are able to generate valid results) and personnel and laboratory reputation.

\section{ACKNOWLEDGEMENTS}

This work was done within the project no. 23ELI/01.09.2016, the ELI-RO programme financed by the National Authority for Scientific Research and Innovation (ANCSI).

\section{REFERENCES}

[1]. Bhatt B. C. Radiat Prot Environ 34 (2011) 6-16.

[2]. Tuncel N., Karayalcin B., Koca G. International Journal of Medical Physics, 2014; 2 (1): ??

[3]. Rhynert C. R., Miller W. G. Health Phys.18 (1970) 681-4.

[4]. Pradhan A. S., Lee J. I., Kim J. L. J Med Phys. 33 (2008) 85-99. 
[5]. Sahoo G. S., Tripathy S. P., Paul S., Sharma S. D., Sharma S. C., Joshi D. S., Bandyopadhyay T. J Med Phys. 39-4 (2014) 225-230.

[6]. Deutsches Atomforum e.V., Berlin (Germany); Kerntechnische Gesellschaft e.V., Bonn (Germany); 1004 p; 2009; 4 p; Annual meeting on nuclear technology 2009; Jahrestagung Kerntechnik 2009; Dresden (Germany); 12-14 May 2009, A. Jahn, M. Sommer, J. Henniger, Radiation Protection and Dosimetry (S61).

[7]. Stochioiu A., Luca A., Sahagia M., Margineanu R. M., Tudor I. Journal of Environmental Radioactivity 112 (2012) 4-7.

[8]. ISO/IEC 17025:2005 - General requirements for the competence of testing and calibration laboratories.

[9]. National Commission for Nuclear Activities Control, Norms on Individual Dosimetry, NSR-06, Bucharest, 2002.
[10]. European Commission Radiation Protection No. 160 - Technical Recommendations for Monitoring Individuals Occupationally Exposed to External Radiation, 2009.

[11]. M. Sommer, A. Jahn, R.M. Praetorius, D. Sommer, J. Henniger, WM2012 Conference. Phoenix, AZ.

[12]. SR EN 62387-1:2012 ver.eng. - Radiation protection instrumentation - Passive integrating dosimetry systems for environmental and personal monitoring Part 1: General characteristics and performance requirements

[13]. ISO 21909-1:2015 - Passive neutron dosimetry systems - Part 1: Performance and test requirements for personal dosimetry

[14]. ISO 8529-3:1998 - Reference neutron radiations - Part 3: Calibration of area and personal dosimeters and determination of response as a function of energy and angle of incidence. 